\title{
The Behavior of a Foundation Laterally Loaded at the Top over Highly Porous and Collapsible Soil
}

\author{
Roberto Kassouf $^{1(\bowtie)}$, David de Carvalho ${ }^{2}$, \\ Paulo José Rocha de Albuquerque ${ }^{2}$, and Nelson L. Fonte Jr. ${ }^{3}$ \\ ${ }^{1}$ Metropolitan College of Campinas - DeVry Metrocamp, Campinas, Brazil \\ Kassouf. engenharia@kassouf.com.br \\ 2 State University of Campinas, Campinas, Brazil \\ d33c@uol.com.br,pjra@fec.unicamp.br \\ ${ }^{3}$ Head of Geoponto Engineering, Mogi das Cruzes, São Paulo, Brazil \\ lopesfontejr@bol.com.br
}

\begin{abstract}
In geotechnical engineering, the problem of laterally top-loaded piles occurs frequently. This type of foundation is often used in highly porous, collapsible soils, which are common in several regions of Brazil. Because of the limited information available in the literature, several load tests have been performed on piles subjected to this load. To analyze the behavior of piles in these collapsible soils, load tests were performed in steel piles (I), W $250 \times 32.7$ section $(\mathrm{mm} \times \mathrm{kg} / \mathrm{m})$, length $12 \mathrm{~m}$, conventional bored piles $(\phi=0.40 \mathrm{~m} ; \mathrm{L}=12 \mathrm{~m})$ and continuous helical auger piles $(\phi=0.40 \mathrm{~m}$; $\mathrm{L}=12 \mathrm{~m}$ ). All of them were tested at the same site. For each type of pile, a first load test was carried out with the soil in its natural condition of moisture content, followed by a second load test after the surface soil was flooded for $48 \mathrm{~h}$. The results indicated a significant negative effect of flooding on the topsoil which consisted of sandy-silty clay with collapsible features down to the depth of $6 \mathrm{~m}$. Load vs. horizontal displacement curves and soil coefficients of horizontal reaction were obtained. The results allowed the proposal of parameters for use in the soil under study. Before executing the load tests, laboratory and in-situ tests were performed to investigate the local subsoil.
\end{abstract}

Keywords: Laterally load tests $\cdot$ Piles $\cdot$ Porous soil $\cdot$ Collapsible soil

\section{Introduction}

The deep foundation designer, in addition to the executive-system-related aspects and the type of material employed, is concerned with the loading system, which can produce displacements due to axial load, transversal load and bending moments. Regarding lateral loading, the top of foundations is generally subject to these forces. This is the case of bridges, viaducts, transmission line towers, wind power generation towers, or along the piles shaft due earth's pressure. In countries with seismic activities, the construction code requires consideration of the horizontal load in foundation designs, thus minimizing the consequences of a possible earthquake. 
When dimensioning foundations to resist lateral loads, the project criteria involve not only the ultimate horizontal loading capacity, but also the maximum pre-established displacement that can occur. Currently, there are many mathematical methods for prediction of the horizontal displacement of a pile. The common difficulty about these methods concerns the adoption of geotechnical parameters to be used in the calculations.

The main parameter used is the modulus of horizontal reaction $\left(n_{h}\right)$, which is defined as the soil resistance along the foundation divided by its deflection at a point. Simplified mathematical models have been created for the analysis because the modeling of the transversal action problem is three-dimensional and extremely complex for routine solutions by project designers. The most commonly known and widespread theory for evaluation of these actions is the "Theory of Horizontal Reaction of the Soil", where the $n_{h}$ factor represents the proportionality between the reaction and displacement acting on the soil mass. However, this factor is difficult to be theoretically estimated. Nevertheless, this factor can be "measured" using load tests to get a reliable value for horizontal resistance of the soil where the construction is to take place.

The reaction of the soil is a function of many factors, such as pile properties, soil stress vs. strain behavior, depth of the point analyzed, level of foundation displacement, etc. Because of the difficulty to establish a function covering all of these factors, the simplified Winkler's (1875) hypothesis is generally used, where the reaction of the soil is considered proportional to the displacement of the pile.

For horizontal loading, in the first few meters the surface soil has great influence on the load vs. lateral displacement behavior of the foundations. To predict the behavior of horizontally loaded foundations, theoretical approaches are available in the literature; however, parameters should be determined for the local soil before they can be used.

Surface soils with porosities above $50 \%$ cover vast areas in Midwest Brazil. Because of their large void volumes, these soils undergo great strain under load. In addition, many of these soils are collapsible, i.e., when the soils are under load and when a significant increase in the moisture content or soil saturation occurs, the structure collapses, which results in unacceptable displacement values for the buildings.

Given the lack of available information in the literature concerning horizontally loaded piles on highly porous collapsible diabase soil, this study was developed in order to review the performance of three types of piles in this type of soil. The tests were performed with the soil at their natural moisture content and after flooded on the surface.

Based on the horizontal loading tests, the effect of soil flooding on the load $v s$. horizontal displacement curve and the values for the horizontal reaction coefficient for both the natural and pre-flooded soil conditions were verified. The results obtained for the horizontal reaction coefficient were compared to the results for other types of foundations on similar soils.

The acting stresses and displacements on a pile under bending moments and horizontal loadings were determined using the theory of soil horizontal reaction, which is based on the model proposed by Winkler (1875). The soil behavior under horizontal forces is simulated by a set of independent, identical and equally spaced springs. Thus, the reaction of the soil is considered proportional to the displacement of the point being analyzed. This supposition simplifies the problem, considering that the ratio between 
the pressure of contact at the base of the foundation and its corresponding consolidation is the same for any supporting area. Using the model proposed by Winkler, the concept of the modulus of horizontal reaction, K, was introduced by Terzaghi (1955). It is defined as the ratio between the reaction of the soil (in units of force applied by the pile length) and the corresponding displacement (Eq. 1):

$$
\mathrm{K}=\frac{p}{y}
$$

Where: $\mathrm{K}=$ the modulus of horizontal reaction $\left(\mathrm{FL}^{-2}\right), \mathrm{p}=$ the applied pressure $\left(\mathrm{FL}^{-1}\right)$ and $\mathrm{y}=$ the horizontal displacement $(\mathrm{L})$.

This notation presents the advantage of being independent of the diameter of the foundation. Therefore, the Eq. 2 can be rewritten as:

$$
\mathrm{K}=\mathrm{k}_{\mathrm{h}} \cdot \mathrm{D}
$$

Where: $\mathrm{k}_{\mathrm{h}}=$ the horizontal reaction coefficient $\left(\mathrm{FL}^{-3}\right)$ and $\mathrm{D}=$ the diameter of the foundation (L).

For pure sands, the elasticity modulus increases (approximately) linearly with depth. Therefore, the soil reaction to the load applied to the pile is assumed to increase linearly with depth (Eq. 3):

$$
\mathrm{K}=\frac{\mathrm{p}}{\mathrm{y}}=\mathrm{n}_{\mathrm{h}} \cdot \mathrm{z}
$$

Where: $n_{h}=$ the modulus of the horizontal reaction of the soil $\left(\mathrm{FL}^{-3}\right)$ and $\mathrm{z}=$ the depth (L).

Understanding the variation of $\mathrm{K}$ along the foundation is required for analysis of its behavior based on the theory of soil reaction. Refinements and sophistications in the reaction modulus function by depth are not justified since the errors in the results of calculations are minor compared with the ones involved in the estimation of numerical values of the modulus of soil reaction. Matlock and Reese (1960) agree with this assessment because the results are satisfactory and can be obtained for most practical cases as simple forms of variation of the reaction modulus with depth. Additionally, in practical problems, the uncertainty inherent to the estimation of soil behavior based on conventional tests is generally compatible with the minor errors that can be introduced by the depth using a simple form of the soil reaction modulus function.

Alizadeh and Davisson (1970) were the first researchers to present curves obtained for horizontal loads tests on sandy soils. They presented these curves in the form of $n_{h}$ at the $y$-axis and the displacement $\mathrm{y}_{0}$ at the $\mathrm{x}$-axis. To create these curves, the authors used Eq. (4) by Matlock and Reese for the displacement for the application of only one horizontal load parallel to the ground surface, i.e.:

$$
y_{o}=\left(\frac{H T^{3}}{E_{p} I_{p}}\right) \Delta_{y}
$$


Where: $\mathrm{T}$ is the relative stiffness between the pile and the soil, and for soils with sandy behavior and normally consolidated clays. It is defined by Eq. 5:

$$
T=\sqrt[5]{\frac{E_{p} I_{p}}{n_{h}}}
$$

To calculate $\mathrm{n}_{\mathrm{h}}$, Eq. 6 is used:

$$
n_{h}=\frac{4,42 H^{5 / 3}}{y_{o}^{5 / 3}\left(E_{p} I_{p}\right)^{2 / 3}}
$$

In the present study, the soil characteristics were analyzed using geotechnical laboratory tests and in-situ tests, with the aim of predicting soil behavior in terms of deformability, resistance and collapsibility. To determine the horizontal reaction coefficient $\left(\mathrm{n}_{\mathrm{h}}\right)$, curves of horizontal reaction coefficients $\left(\mathrm{n}_{\mathrm{h}}\right)$ vs. horizontal displacement at the surface $\left(\mathrm{y}_{\mathrm{o}}\right)$ were calculated based on the load tests performed and adopting a range of values of horizontal displacement. Alizadeh and Davisson (1970) proposed the curves $\left(\mathrm{n}_{\mathrm{h}}\right)$ vs. $\left(\mathrm{y}_{\mathrm{o}}\right)$ using values in the $6.35-12.70 \mathrm{~mm}$ range. The curves of horizontal reaction coefficients $v s$. horizontal displacement were divided into two separate groups: load tests performed with soil in its natural moisture content and load tests performed with the soil pre-flooded on the surface.

\section{Materials and Methods}

The aims of this study were achieved based on geotechnical analysis of the soil under investigation, execution of piles, conduction of load tests on piles and analysis of the obtained data.

\subsection{Geological and Geotechnical Characteristics}

The soil is composed of diabase bodies which can also be found embedded in the Itararé Formation and in the Crystalline Complex in the form of sills and dykes. Such materials are pedologically classified as purple latosols, and are mineralogically constituted by quartz, ilmenite, magnetite, kaolinite, gibbsite, iron oxides and hydroxides. Thicknesses range from 5 to $30 \mathrm{~m}$. (Zuquete 1987).

The load tests were carried out at the Experimental Site of the University of Campinas (Cavalcante et al. 2007), where the profile of the subsoil is diabase soil. It has a highly thick 6-m thick sandy-silty clay surface layer followed by a sandy-clayey silt layer down to the depth of $19 \mathrm{~m}$. The water table is found at the depth of $18 \mathrm{~m}$. The mean geotechnical profile of the subsoil was obtained from the results of tests on undeformed samples taken after opening two wells and performing Standard Penetration Tests (SPT) and Static Penetration Tests (CPT). The results of the laboratory tests and field tests performed can be found in Peixoto (2001), Fig. 1. 


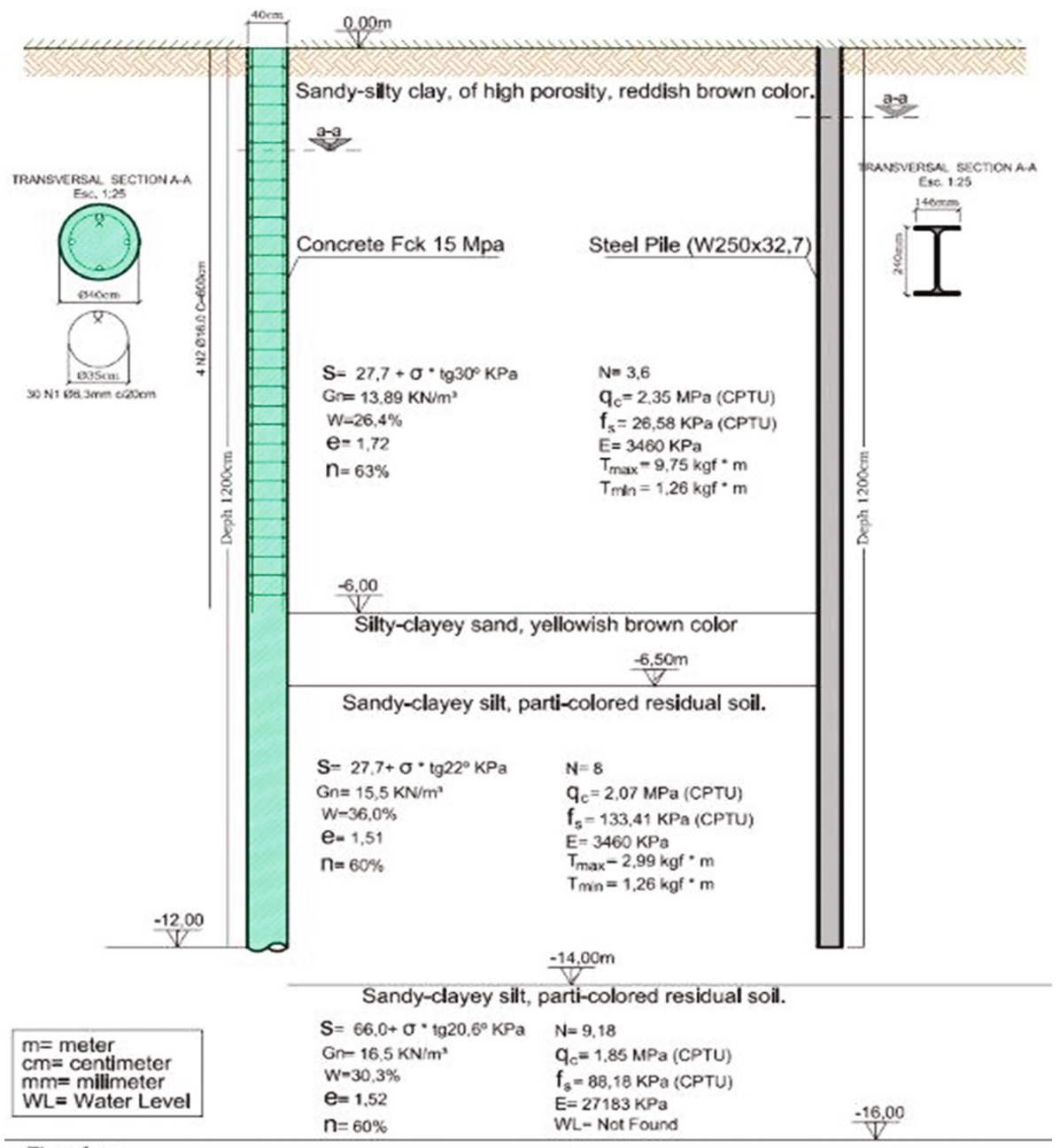

Therefore:

$\mathrm{S}=$ Shear resistance equation - triaxial test; $\mathrm{Gn}$ - Apparent specific gravity; $\mathrm{W}=$ Moisture Content

$\mathrm{e}=$ Voit ratio; $\mathrm{n}=$ Porosity; $\boldsymbol{\mu}=$ Polsson's ratio; $\mathrm{N}=$ Average SPT value; $\mathrm{qC}=$ Average point resistence;

fs= Average skin friction; $E=$ Elastic Modulus: $T=$ Average torque value; $K=$ Permeability ratio.

Fig. 1. Static Penetration Tests (CPT) and the results of the laboratory tests and field tests performed Peixoto (2001).

The characteristics of collapsibility of the subsoil of the Experimental Site were reviewed by Monacci (1995). The criterion used was the one proposed by Vargas (1978), which defines soils as collapsible when the coefficient of structural collapse, "i", is greater than $2 \%$, considering that "i" is defined by the following equation:

$$
\mathrm{i}=\frac{\Delta e c}{1+e i}
$$


In the equation above, $\Delta \mathbf{e}_{\mathbf{c}}$ represents the variation in the void ratio due to collapse of the soil structure, and $\mathbf{e}_{\mathbf{i}}$ is the index of voids before flooding.

The indexes of collapse at the depths of $0.75 \mathrm{~m}, 5.00 \mathrm{~m}$ and $8.00 \mathrm{~m}$, were determined from simple oedometric tests, with soil flooded at determined pressures, which are presented in Table 1. Note that collapsibility in the layer of high porous soil is reduced as a function of depth.

Table 1. Collapse coefficients according to the applied voltage and the depth - Monacci (1995)

\begin{tabular}{l|l|l|l|l|l}
\hline \multicolumn{2}{l|}{ Depth 0,75 m } & \multicolumn{2}{l|}{ Depth 5,00 m } & \multicolumn{2}{l}{$\begin{array}{l}\text { Depth } \\
8,00 \mathrm{~m}\end{array}$} \\
\hline \multirow{2}{*}{$\sigma(\mathrm{kPa})$} & $\mathrm{i}$ & \multirow{2}{*}{$\sigma(\mathrm{kPa})$} & $\mathrm{i}$ & $\sigma(\mathrm{kPa})$ & $\mathrm{i}$ \\
\cline { 2 - 6 } & $(\%)$ & & $(\%)$ & & $(\%)$ \\
\hline 5 & 4,97 & - & - & - & - \\
\hline 9,8 & 11,09 & 9,8 & 2,41 & - & - \\
\hline 19,4 & 7,4 & 19,4 & 3,76 & - & - \\
\hline
\end{tabular}

Gon (2011) performed oedometric tests with stresses of $100 \mathrm{kPa}, 200 \mathrm{kPa}$ and $400 \mathrm{kPa}$. The samples taken at $1 \mathrm{~m}$ of depth were observed to be collapsible, with a very high index for all flooding stresses. For the $2 \mathrm{~m}$ and $3 \mathrm{~m}$ deep layers, it was possible to observe the low collapsibility index for the $100 \mathrm{kPa}$ and $200 \mathrm{kPa}$ stress, which in turn had a high index for the $400 \mathrm{kPa}$ stress. Based on the data obtained for the $100 \mathrm{kPa}$ stress, only the $1 \mathrm{~m}, 4 \mathrm{~m}$ and $8 \mathrm{~m}$ depths were observed to be collapsible. However, for the $200 \mathrm{kPa}$ stress, only the $2 \mathrm{~m}$ and $3 \mathrm{~m}$ depths were not collapsible. Finally, for the flooding stress of $400 \mathrm{kPa}$, all of the depths were observed to be collapsible, with the exception of the $8 \mathrm{~m}$ depth.

\section{Load Tests}

\subsection{Piles Analyzed}

\subsubsection{Steel Piles}

A $12 \mathrm{~m}$ long steel pile I was used; $250 \times 32.7$ section $\mathrm{W}(\mathrm{kg} \times \mathrm{mm} / \mathrm{m})$; Moment of Inertia Ix $=4,937 \mathrm{~cm}^{4}$; Young's Modulus E = 205,000 $\mathrm{MPa}$ and Area $=42.1 \mathrm{~cm}^{2}$; in Gerdau (2015). The pile dimensions are shown in Fig. 2.

\subsubsection{Continuous Flight Auger Piles and Bored Piles}

These piles were constructed with $0.40 \mathrm{~m}$ nominal diameter and $12 \mathrm{~m}$ length. The concrete used in continuous flight auger piles were pumped, cement consumption of $400 \mathrm{~kg} / \mathrm{m}^{3}$ and aggregates (sand and gravel); slump $\pm 240 \mathrm{~mm}$. The characteristic compression resistance of concrete (fck) was $15 \mathrm{MPa}$, slump $\pm 70 \mathrm{~mm}$, using gravel and sand as aggregates. The longitudinal frame of both piles were 4 bars with 


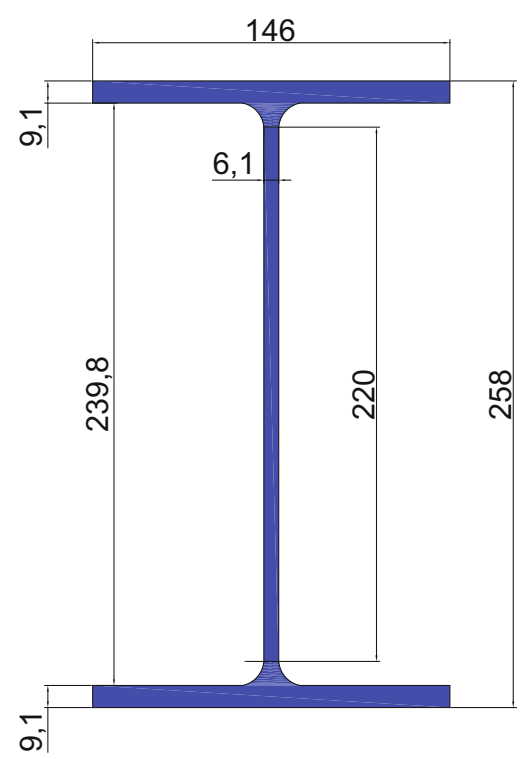

Fig. 2. Steel pile dimensions

$16 \mathrm{~mm}$ diameter, CA-50 steel, $6 \mathrm{~m}$ long, plus a $12 \mathrm{~m}$ long Dywidag steel bar with $32.0 \mathrm{~mm}$ diameter positioned in the center of the pile. The stirrups were $6.3 \mathrm{~mm}$ every $20 \mathrm{~cm}$. The Young's modulus of these piles was in average $20 \mathrm{GPa}$ (Miranda Junior 2006).

\subsection{Results and Analysis}

Based on the results of the load tests, load vs. horizontal displacement curves were obtained.

The results for steel piles are shown in Fig. 3.

Figures 4 and 5 show the results for bored and continuous flight auger piles.

The load tests were conducted for the three types of piles with slow maintained loads. The pre-flooding of the soil was conducted for $48 \mathrm{~h}$ through an excavation around pile head with the head of $0.70 \mathrm{~m} \times 0.70 \mathrm{~m}$ and $0.50 \mathrm{~m}$ depth

It is observed that:

Pre-flooding the topsoil caused drastic reduction of soil resistance to horizontal loading. Taking a $5 \mathrm{~mm}$ displacement as reference for the steel pile into the natural moisture content soil, the supported load is approximately $50 \mathrm{kN}$, whereas for the pre-flooded soil for this displacement, the supported load is approximately $3 \mathrm{kN}$. For bored piles in the natural moisture content soil for $5 \mathrm{~mm}$, the supported load is about $48 \mathrm{kN}$, while for the pre-flooded soil for this displacement, the supported load is about $8 \mathrm{kN}$. For continuous flight auger piles, the supported load is about $45 \mathrm{kN}$ in soil in its natural moisture content, whereas for pre-flooded soil for this displacement of $5 \mathrm{~mm}$, the supported load is about $2 \mathrm{kN}$. 


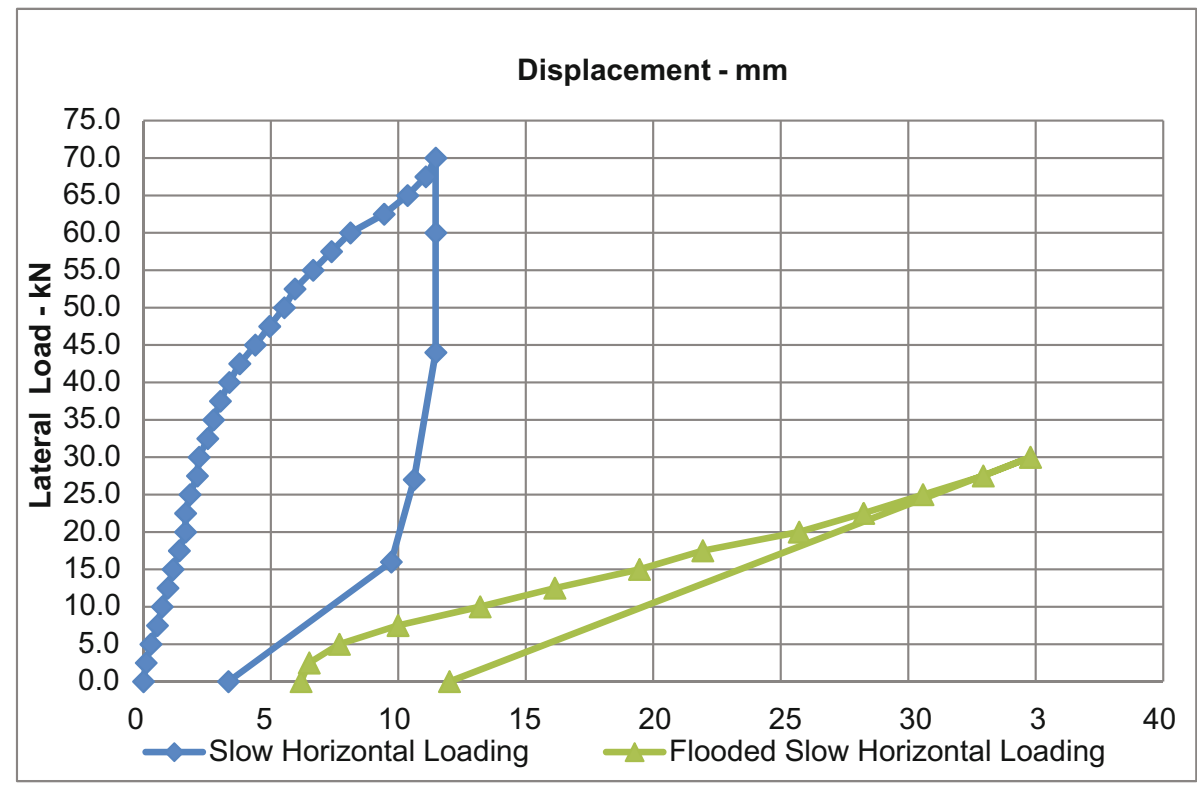

Fig. 3. Load vs. horizontal displacement curves on Steel Pile $(\mathrm{W} 250 \times 32,7) \mathrm{mm} \times \mathrm{kg} / \mathrm{m}$; $\mathrm{L}=12 \mathrm{~m}$.

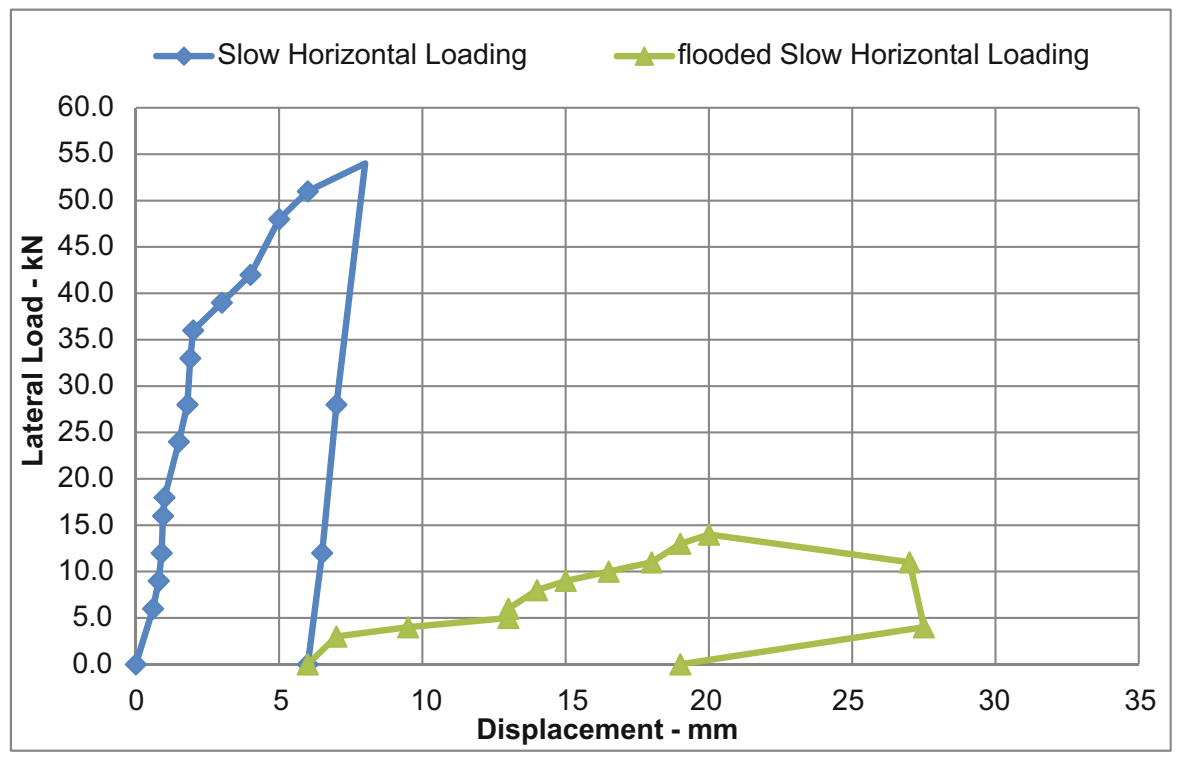

Fig. 4. Load vs. horizontal displacement curves - Bored pile $(\phi=0,40 \mathrm{~m} ; \mathrm{L}=12 \mathrm{~m})$ 


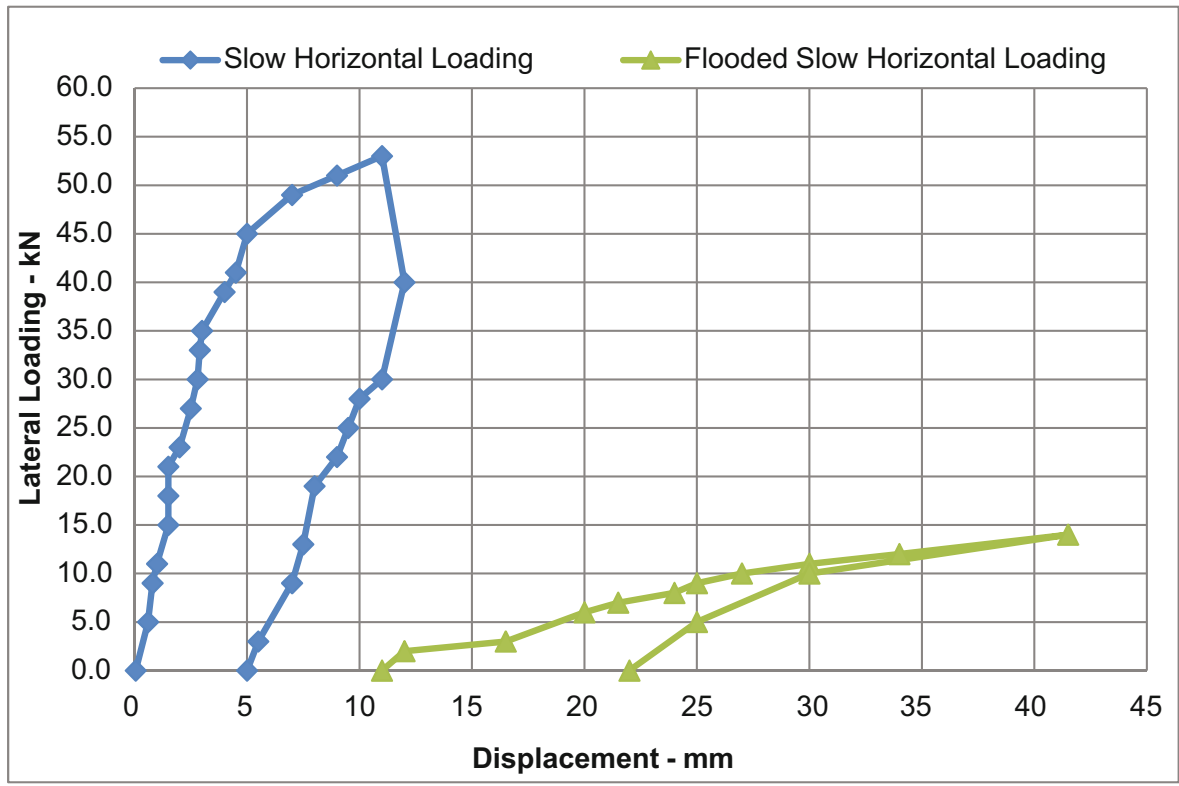

Fig. 5. Load vs. horizontal displacement curves - Continuous flight auger $(\phi=0,40 \mathrm{~m}$; $\mathrm{L}=12 \mathrm{~m})$

Table 2. Values of horizontal loads, displacements and horizontal reaction coefficients. Source: The authors.

\begin{tabular}{|c|c|c|c|c|}
\hline \multirow{2}{*}{$\begin{array}{l}\text { Type } \\
\text { pile }\end{array}$} & Author & Local & \multirow{2}{*}{$\begin{array}{l}\text { Soil } \\
\text { condition }\end{array}$} & \multirow{2}{*}{$\begin{array}{l}\mathrm{n}_{\mathrm{h}}\left(\mathrm{MN} / \mathrm{m}^{3}\right) \text { displacement } 6 \text { to } \\
12 \mathrm{~mm}\end{array}$} \\
\hline & Name & Brazil & & \\
\hline \multirow[t]{2}{*}{ Steel } & \multirow{2}{*}{$\begin{array}{l}\text { Silva, } \\
\text { Marcella B.M }\end{array}$} & \multirow[t]{8}{*}{ Unicamp } & Natural & 7.71 \\
\hline & & & Flooded & 0.40 \\
\hline \multirow[t]{2}{*}{ Bored } & \multirow{2}{*}{$\begin{array}{l}\text { Miranda Jr., } \\
\text { Gentil }\end{array}$} & & Natural & 11.55 \\
\hline & & & Flooded & 0.56 \\
\hline \multirow[t]{2}{*}{ CFA } & \multirow{2}{*}{$\begin{array}{l}\text { Miranda Jr., } \\
\text { Gentil }\end{array}$} & & Natural & 9.86 \\
\hline & & & Flooded & 0.24 \\
\hline \multirow[t]{2}{*}{ Caisson } & \multirow{2}{*}{$\begin{array}{l}\text { Kassouf, } \\
\text { Roberto }\end{array}$} & & Natural & 12 \\
\hline & & & Flooded & 6 \\
\hline
\end{tabular}




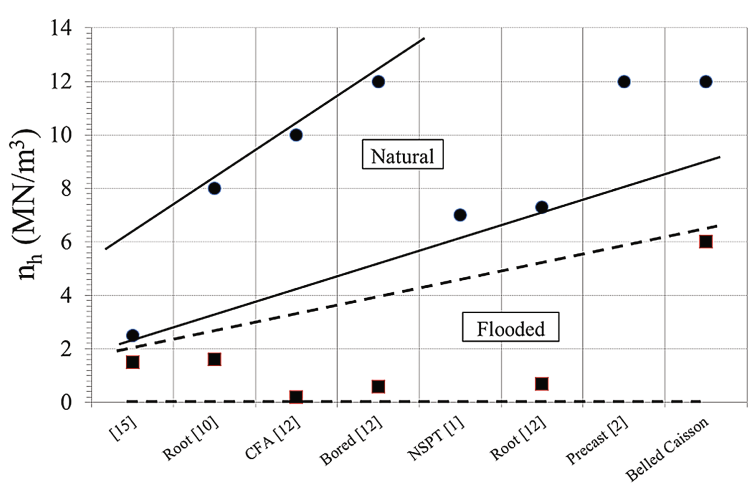

Fig. 6. Graph of nh vs. authors load tests.

\section{Conclusions}

The load tests have indicated that the soil has low bearing capacity to horizontal loading, even in its natural condition of moisture content. These results reinforce the need to perform load tests on these types of soil to get precise parameters for projects.

High variation in moisture content down to a few meters deep into the soil significantly reduces the piles ability to support horizontal loadings. Thus, in foundations subject to such loading in these types of soils, care should be taken to minimize this possibility, both in the case of leakage in piping and in the case of infiltration by rain water.

The permeability coefficients of this soil both in its natural condition and in the compacted condition are in the range between $5 \times 10^{-4} \mathrm{~cm} / \mathrm{s}$ and $5 \times 10^{-7} \mathrm{~cm} / \mathrm{s}$, respectively.

The values of horizontal coefficients $n_{h}$ obtained from the analysis of steel piles, bored piles and flight auger piles, that are presented in Table 2, differ from the literature for different types of deep foundations built on soil with similar behavior to the one from the present study (under natural and pre-flooded conditions) are presented in Fig. 6.

However, these values are within the range of values $n_{h}$ found for sandy porous soils of the State São Paulo, Brazil. Miguel (1996) found 7.50 and $8.0 \mathrm{MN} / \mathrm{m}^{3}$ for bored, Strauss and root piles, respectively. Ferreira et al. (2001) obtained values $n_{h}$ of 7.4 and $11.0 \mathrm{MN} / \mathrm{m}^{3}$ for bored piles in the city of Bauru. Souza et al. (2008) got the value of $5 \mathrm{MN} / \mathrm{m}^{3}$ for bored piles in Ilha Solteira. For the Experimental Site under analysis, Miranda Junior (2006) obtained the average values $n_{h}$ of $7.28 \mathrm{MN} / \mathrm{m}^{3}$ for root piles, $9.86 \mathrm{MN} / \mathrm{m}^{3}$ for continuous flight auger piles and $11.55 \mathrm{MN} / \mathrm{m}^{3}$ for bored piles.

Carvalho et al. (1996) obtained the value of $11.90 \mathrm{MN} / \mathrm{m}^{3}$ for pre-cast concrete piles. 
Kassouf (2012) had to place close to the same type of soil the value obtained the value of $12 \mathrm{MN} / \mathrm{m}^{3}$ for a caisson, for the same type of soil in a place close the Experimental Site.

The results of load tests conducted by Miranda Junior (2006) show that the reinforced concrete blocks in the pile head can increase load capacity of both natural moisture content soil and soil with significant variations of moisture content.

For collapsible soils, the analysis of the possibility of water saturation or large variations in moisture content of the surface soil up to few meters, during the construction service life, are of fundamental importance to determine the project parameters.

Acknowledgments. The authors thank the Unicamp-Universidade Estadual de Campinas, the FAPESP-Fundação de Amparo à Pesquisa do Estado de São Paulo and DeVry MetrocampMetropolitan College of Campinas.

\section{References}

Alizadeh, M., Davisson, M.T.: Lateral load tests on piles - arkansas river project. J. Soil Mech. Found. Div. ASCE 96(SM5), 1583-1604 (1970)

Carvalho, D., Albuquerque, P.J.R., Claro, A.T., Ferreira, C.V.: Análise de estaca carregada transversalmente no topo, em solo residual de diabásio, Seminário de Engenharia de Fundações Especiais (SEFE 3), vol. 1, pp. 145-154 (1996)

Gerdau - Perfis Gerdau Açominas aplicados como Estacas Metálicas em Fundações Profundas. $8^{\mathrm{a}}$ edição (2015)

Gon, F.S.: Caracterização geotécnica através de ensaios de laboratório de um solo de diabásio da região de Campinas/SP. M.S thesis. Department of Geotechcnics and Transportation, University of Campinas, Campinas, Brasil (2011)

Kassouf, R.: Análise de Prova de Carga em Tubulão a Céu Aberto Submetido a Esforço Horizontal em Solo não Saturado de Diabásio da Região de Campinas. Dissertação de Mestrado. Universidade Estadual de Campinas, SP (2012). 111p.

Matlock, H., Reese, L.C.: Generalized solutions for laterally loaded piles. J. Soil Mech. Found. Eng. Div. ASCE 86(SM5), 63-91 (1960)

Miguel, M.G.: Execução e análise de provas de carga horizontal em estacas em solo colapsível. M.S. thesis. Departament of Geotechcnics, University of São Paulo, São Carlos, Brasil (1996)

Miranda, J.G.: Estacas Submetidas a Esforços Horizontais em Solos Colapsíveis do Interior de São Paulo nas Condições Natural, Melhorada e Inundada. Ph.D. Dissertation, Faculty of Agricultural Engineering, University of Campinas, Campinas (2006)

Monacci, M.G.: Estudo da Colapsibilidade de um Solo do Campo experimental da Faculdade de Engenharia Agrícola, Unicamp. Dissertação de Mestrado, Faculdade de Engenharia Agrícola. Unicamp, p. 130 (1995) 
Peixoto, A.S.P.: Estudo do ensaio SPT - T e sua aplicação na pratica de engenharia de fundações - tese de doutorado, Faculdade de engenharia agricola, Unicamp (2001). 468p.

Terzaghi, K.: Evalution of Coefficients of Subgrade Reaction. Géotechnique 5(4), 297-326 (1955)

Vargas, M.: Introdução à Mecânica dos Solos. McGraw -Hill do Brasil, São Paulo (1978)

Zuquete, L.V.: Análise e proposta metodológica sobre cartografia geotécnica para condições brasileiras, Tese de Doutorado, vol. 3. EESCUSP, São Carlos (1987) 